\title{
Abbreviations and glossary of terms
}

$\begin{array}{ll}\text { BCP } & \begin{array}{l}\text { Bulgarian Communist Party } \\ \text { Brezhnev Doctrine } \\ \text { Doctrine that sanctioned Soviet intervention in } \\ \text { the domestic affairs of Eastern Europe countries } \\ \text { whenever the socialist order was perceived to be } \\ \text { under threat, for instance in Czechoslovakia in 1968 }\end{array} \\ \text { BSP } & \begin{array}{l}\text { Bulgarian Socialist Party } \\ \text { Bundestag }\end{array} \\ \text { Bundeswehr } & \text { (West) German parliament } \\ \text { BZNS } & \text { Bulgarian Agrarian National Union } \\ \text { CC } & \text { Central Committee (of Communist Party) } \\ \text { CDU } & \text { Christian Democratic Union (West Germany) } \\ \text { COMECON } & \text { Council for Mutual Economic Aid } \\ \text { CPSU } & \text { Communist Party of the Soviet Union } \\ \text { CPUN } & \text { Provisional Council of National Unity (Romania) } \\ \text { CSCE } & \text { Conference on Security and Cooperation in Europe } \\ \text { EC } & \text { European Community } \\ \text { Ecoglasnost } & \text { Bulgarian pressure group } \\ \text { END } & \text { European Campaign for Nuclear Disarmament } \\ \text { EU } & \text { European Union } \\ \text { FDP } & \text { Free Democrat Party (West Germany) } \\ \text { FRG } & \text { Federal Republic of Germany (West Germany) } \\ \text { FSN } & \text { National Salvation Front (Romania) } \\ \text { GDR } & \text { German Democratic Republic (East Germany) } \\ \text { glasnost } & \text { Gorbachev's policy of 'openness' } \\ \text { IFM } & \text { Initiative for Peace and Human Rights (GDR) } \\ \text { IMF } & \text { International Monetary Fund } \\ & \end{array}$


KGB

KOR

KPD

KSČ

Die Linke

MDF

MFN

MfS

MRF

MSzMP

$\mathrm{MSzP}$

NATO

Neues Forum

nomenklatura

NVA

NZS

OMGUS

PD-L

PDS

perestroika

PNL

PNT,

Podkrepa

Politburo

PSD

PZPR

RSA

samizdat

SDI

Securitate

SED

Sejm

Solidarity

SPD
Committee for State Security (USSR)

Workers' Defence Committee (Poland)

Communist Party of Germany

Communist Party of Czechoslovakia

The Left, German political party, successor to the PDS

Hungarian Democratic Forum

Most-favoured nation

Ministry for State Security (GDR), better known as the Stasi

Movement for Rights and Freedom (Bulgaria)

Hungarian Socialist Workers' Party

Hungarian Socialist Party

North Atlantic Treaty Organisation

New Forum, East German dissident group

List of key administrative appointments approved by the party

National People's Army (GDR)

Independent Students' Association (Poland)

Office of Military Government (American)

Liberal Democratic Party (Romania)

Party of Democratic Socialism (GDR/Germany)

Gorbachev's policy of 'restructuring' or 'reconstruction'

National Liberal Party (Romania)

National Peasant Party (Romania)

'Support', independent Bulgarian trade union

Leading body of communist parties

Social Democratic Party (Romania)

Polish United Workers' Party

Movement for an Alternative Society (Poland)

Self-publishing

Strategic Defence Initiative

Romanian secret police

Socialist Unity Party of Germany (GDR)

Lower house of the Polish parliament

Independent (non-communist) Polish trade union

Social Democratic Party of Germany (West

Germany) 
Stasi

UDF

UDMR/RMDSz

UN

USSR

Volkskammer

Warsaw Pact

WiP
East German secret police

Union of Democratic Forces (Bulgaria)

Democratic Union of Hungarians in Romania

United Nations

Union of Soviet Socialist Republics

East German parliament

Soviet-led military organisation

Freedom and Peace Movement (Poland) 